\title{
Evaluation of the Block System Implementation at Permata Harapan Vocational High School
}

\author{
Miftahul IImi ${ }^{1}$, Kasman Rukun ${ }^{2}$
}

1,2 Program Studi Pendidikan Teknologi Kejuruan, Universitas Negeri Padang, Indonesia

\begin{tabular}{l} 
A R T I C L E I N F O \\
\hline Article history: \\
Received 18 February \\
2020 \\
Received in revised \\
Form 29 March 2020 \\
Accepted 18 April 2020 \\
Available online 29 May \\
2020 \\
\hline Keyword \\
Block system, Vocational, \\
CIPP
\end{tabular}

A R T I C L E I N F O

Received 18 February 2020

Accepted 18 April 2020

Available online 29 May

Keyword CIPP

\begin{abstract}
A B S T R A C T
This study aimed to evaluate the block system implementation in Permata Harapan Vocational High School based on (1) understanding and apply the block system conducted by teaching staff, (2) understanding of block system implementation by students, (3) availability of facilities and infrastructure at Permata Harapan Vocational High School to support good student competence. This research was a descriptive study. Data was collected by using a questionnaire method based on the CIPP evaluation model (context, input, process, product). The subjects of this study were 50 students in grade X and XI Permata Harapan School and several officials high school. The description of the data carried out by considering the frequency distribution and determining the Level of Respondent Achievement (TPR) in each component and indicator which compared with the criteria. The results showed that the scores were based on an understanding of the implementation of the block system using the CIPP evaluation method which included in moderate category and reached $68.65 \%$ percent, with details of each aspect: (1) the context aspect was $81.94 \%$, (2) $63.89 \%$ of input aspects, (3) $67.70 \%$ of process aspects, (4) $71.52 \%$ of product aspects. Based on the discussion results of observation and documentation, the average achievement of all aspects was $82.47 \%$. So, the implementation of the block system at SMK Permata Harapan has been in good classification but it still needs improvement in various aspects so that the goal of implementing the block system can be achieved perfectly.
\end{abstract}

\section{Introduction}

The rapid development of information technology has brought the world to a new era where technological developments are more sophisticated than previously imagined. The development of this technology brings changes in various fields, especially the industrial world. As we all know the industrial revolution has reached the 4.0 industrial revolution and wireless-based automation by prioritizing speed in doing work. The speed of processing and sending information has a very important role in every sector, especially in sectors that have a high level of routine and have demands to get the job done very quickly. This situation requires the sector of human resource (HR) providers to create a new generation that can realize and implement an industrial revolution. To produce quality human resources, the thing that can be done is to improve the quality of education.

Education is a very important capital in living a social life. In the education of Indonesia, we can gain a lot of knowledge such as knowledge about morals, religion, discipline, and many others. This is in line with the understanding of education according to UU No.20 Tahun 2003. Education is a basic and planned effort to create an atmosphere of learning and learning process so that students actively develop their potential to have spiritual strength, self-control, personality, intelligence, morals noble, as well as skills, which are needed by himself, society, and the Country. While some experts also explain the definition of education, among others, Harahap and Poerkatja (in Muhibbin, 2007) state that education is a deliberate effort from parents who are always interpreted as capable of generating moral responsibility for all their actions. According to Heidjrachman and Husnah (in Benny, 2013), education is an activity to improve the general knowledge of a person in increasing understanding of theory and skills, deciding and finding solutions to problems related to activities in achieving its goals, both problems in the world of education or everyday life. Education is a basic effort made by the family, community, and government, through mentoring, teaching and / or training activities, which take place at school and outside of school, 
to prepare students to be able to play a role in various environments in the future, (Mudyaharjo, 2008). Education can be divided into 3 types, formal, informal, and non-formal education.

Formal education is a systematic, structured, multi-level activity starting from elementary school to tertiary level and equivalent, including academic-oriented and general study activities, specialization programs, and professional training carried out in continuous time. Formal education is an educational process that is organized in a way and school environment. This is following the statement of Notoadmodjo (2003: 77), formal education in an organization is a process of developing the ability towards the desired by the organization concerned. According to Pasal 1 ayat 6 Peraturan Pemerintah Nomor 17 Tahun 2010 concerning Management and Implementation of Education, Formal Education is a structured and tiered education pathway consisting of basic education, secondary education, and higher education.

Formal education is a systematic, structured, multilevel, tiered activity, starting from elementary school to tertiary level and equivalent, including academic-oriented and general oriented study activities, specialization programs, and professional training, which are carried out continuously. Besides, formal education is an educational institution that is pursued through institutional channels that have been determined and regulated by a group of authorized people in this case the government or a foundation. One example of formal education in Indonesia is the Vocational High School (SMK).

Vocational High School (SMK) according to the National Education System UU No.20 Tahun 2003 is a form of formal education unit that organizes vocational education at secondary education level following on from junior high schools, MTs, or other equivalent forms. Schools in education and vocational level can be called Vocational High School (SMK) or Vocational Aliyah Madrasah (MAK), or other equivalent forms. According to Edi (2017) vocational high school (SMK) is one of the educational institutions that are responsible for creating human resources who have the ability, skills, and expertise so that graduates can develop performance when engaged in the world of work. Barnawi (2012) explains that the meaning of this education is spelled out more specifically in Peraturan Pemerintah Nomor 29 Tahun 1990 concerning Secondary Education, namely vocational secondary education is secondary education that prioritizes the development of learners' ability to carry out certain types of work.

Vocational Schools have many expertise programs. The expertise program carried out at SMK to the needs of the existing workforce. The expertise program at the Vocational School level also adjusts to the demands of society and the market. So, it can be said that vocational education is secondary education which prepares students especially to be ready to work in certain fields (Abdul, 2012). So, vocational education is an education that prepares students to enter employment (Masbahah, Djoko Kustono 2014).

Permata Harapan School has education levels ranging from Playgroups to Vocational High Schools. This school is one of the schools that has a high vision for the intellectual life of the nation and is located in the Komplek Batu Batam Mas Blok D\&E No. 1, 2, 3, Batam. In terms of formation and preparation, SMK Permata Harapan implements a different learning method in its education system, namely the block system. A Block system is the arrangement of school time where time is in the classroom longer (Zepeda, 1999). The block system regulates class periods to be less, but longer to allow more flexible learning activities. Meanwhile, according to Asril Majid (2011), the block system is learning that combines the hours of study in each face-to-face lesson that was previously conducted once a week until it was completed into a full week or more until the subject was completed, with benchmarks of material can be delivered in a manner maximum and following curriculum demands. According to Wiyananti et al., (2016) system block method is a learning method that focuses on completing one area of expertise before touching another area of expertise, for example, the Department of Software Engineering (RPL) has several materials that are interrelated to one another. Students must master the database before they can build a system. The school will focus students learning only the database within one month until completion and students can master it before they can enter into system design and so on. In this method, the speed of mastery of the material is felt to be very fast and precise because of the focus of learning every day.

The Block system has several advantages (1) giving sufficient time for students to study the material in-depth (Marshak, 1998); (2) more children's learning time and this allows children to work to the end (Suwati, 2008); (3) with longer blocks, teachers have more time to complete lesson plans and to examine and re-evaluate practices and Longer time blocks allow for in-depth studies, such as individual student projects, peer collaboration, and one-on-one work between teachers and students (O'Neil, 1995).

On the teacher and student side, the block system has very good results, but the teacher and student have to work very hard to achieve satisfying results, the teacher must prepare teaching materials and strategies very well so that there are no errors in teaching and students with varying levels of understanding the material being taught. On the student side, this system has several negative impacts, if 
the teacher is not good at managing the class, for example, students will feel bored, sleepy and can even make student interest in learning because every day meets the same lessons continuously for one student (Alni 2019). According to Schott in Majid (2011), the block system has several weaknesses: (1) No significant differences are found in mathematics and reading with other methods. (2) from the results of research by Sacher, R.A., and Mc Pherson (2000) there will be a decrease in learning outcomes in English, Biology, and History subjects because of the boredom felt by students. (3) The ability of students to remember learning outcomes, because they only study certain subjects in one month and the following months do not discuss this lesson again until the end of this semester will produce a memory of these subjects do not always exist permanently. To students. (4) If students are unable to attend due to health conditions, it will be very difficult for students to follow the continuation of the lesson, because learning will continue the next day. On the other hand, Cromwell (1997) also believes that block system learning is learning that aims to attract student activity for a long time, but this does not guarantee that learning will always be active. Agreeing Schott, that the block system will, cause problems for students who cannot attend a class for a longer period for various reasons, because it will make students miss learning material.

In 2018 the government required every school in Indonesia to implement the 2013 Curriculum with the concept of the Kurikulum Tingkat Satuan Pendidikan (KTSP) by having to produce productive human resources and be ready to work in the field, each school must think about their strengths and what methods should be they take so they can outperform other schools in creating quality human resources. Permata Harapan Vocational School chose the block system as its strategy to outperform other schools in terms of the quality of the human resources produced. The problems often faced by Permata Harapan schools that implement the block system are; difficulty arranging lesson schedules so that no two schedules with the same teacher because each class will learn different subjects and some teachers have multiple teaching skills in many subjects, for example, productive teachers who have solid working hours also have science skills will be given Lesson hours in all departments and teachers are productive, so care must be taken to place this schedule, there are also some conflicts with the government regarding exam schedules that are not following what has been prepared by the government (Prasetyo, Novian Yudha 2016).

The purpose and focus of this study are to evaluate the block system implementation in Permata Harapan Vocational High School based on (1) understanding and application of the block system conducted by teaching staff, (2) understanding of the implementation of the block system by students, (3) availability of facilities and infrastructure at Permata Harapan School to support student competencies.

\section{Method}

This research used a descriptive method. The evaluation model used in this study was the CIPP model (context, input, process, product) related to the Block System Implementation. The subject of this study was the evaluation of the application of the block system at SMK Permata Harapan. This study uses a combination model with sequential explanation methods, then data collected used questionnaires and interviews. Questionnaires used for quantitative data collection, while interviews for qualitative data collection. Qualitative data was excavated to find the cause of the problem found in quantitative data. Interviews were conducted with school principals and representatives, teachers, and students. The research was conducted on students of RPL X and XI in Permata Harapan with a total of 43 students, then the Proportional Random Sampling technique was used and the sampling was taken using the formula of Taro Yamane Riduwan (2006) as follows.

$$
n=\frac{M}{1+M \cdot d}
$$

Information

$\mathrm{n} \quad=$ Number of samples

$\mathrm{N} \quad=$ Total population

$\mathrm{d} \quad=$ Percentage of the inaccuracy of errors due to intolerable sampling (10\%)

$$
n=\frac{N}{1+N_{0} d}=\frac{43}{1+43 \times(0.1)^{2}}=30.06=30
$$

Based on the formula above, we can conclude that the sample of this study was 30 students in RPL class $\mathrm{X}$ and XI as many as 30 students. In this study, the results of the questionnaire determined as 
quantitative data with the descriptive analysis method percentage based on the steps. The description of the data carried out by considering the frequency distribution and determining the Level of Respondent Achievement (TPR) in each component and indicator compared with the criteria. The formula used to calculate the TPR:

$$
T P R=\frac{\text { Skor Rata }- \text { rata }}{\text { Skor Maksimal Ideal }} \times 100 \%
$$

Meanwhile, to find statistical data the following formula was used:

$\mathrm{MI}=$ (Ideal Maximum Score + Ideal Minimum Score $) / 2$

$\mathrm{SDI}=($ ideal maximum score - ideal minimum score $) / 6$

Information:

$\mathrm{MI}=$ ideal mean

SDI = ideal Standard Deviation

The data obtained will be compared with Criteria, the criteria elaborated on table 01 .

Table 1. Rating Predicate

\begin{tabular}{ccc}
\hline No & Range & Category \\
\hline 1 & $90-100$ & Very Good \\
2 & $80-89$ & Good \\
3 & $65-79$ & Enough \\
4 & $55-64$ & Less \\
5 & $0-54$ & Not Good \\
\hline & & Source : Sudjana dalam Lubis (2011)
\end{tabular}

\section{Results and Discussion}

\section{Quantitative Data Description}

Quantitative data were collected through a questionnaire consist of 22 questions that have been tested for validity and reliability. Furthermore, the questionnaire was given to 53 students of X and XI grade of Permata Harapan Vocational School to be filled out. The basic statistical calculations collected.

Table 2. Statistical Calculation Results

\begin{tabular}{cc}
\hline Measurable Statistic & Score \\
\hline N Valid & 30 \\
Missing & 0 \\
Mean & 68.8 \\
Median & 68.5 \\
Mode & 68 \\
Deviation Standard & 4.05 \\
Variances & 16.44 \\
Range & 15 \\
Minimum & 75 \\
Maximum & 75 \\
Sum & 60 \\
\hline
\end{tabular}

Table 2 presented that the number of data $(\mathrm{N})$ was 30 , the mean was 68.8 , the median was 68.5 , Mode was 68 , the standard deviation was 4.05 , the variance was 16.44 , the range was 15 , the lowest score was 86, the highest score 75 and the total score was 2064. For the level of attainment of respondents, we can see in the following description:

The following mean (average) score, standard deviations, and bar charts of each research indicator. Descriptions of research data for each aspect presented as follows: 


\section{Student evaluation of context aspects}

Score calculation

Highest ideal score (SMI) : $3 \times 4=12$

Lowest ideal score: $3 \times 1=3$

Ideal mean (Mi) : $\frac{1}{2} x(12+3)=7.5$

The ideal standard deviation (SDi)

$$
: \frac{1}{6} x(12-3)=1
$$

From the results of descriptive analysis, the effectiveness of the implementation of the block system at Sekolah Harapan Harapan from the context aspect showed that the highest score was 12, the lowest score was 8 , while the mean was 10,57 and the standard deviation (SD) was 1.17. The results of the analysis showed in table 03

Table 3. Range of student scores from context aspects

\begin{tabular}{lllcc}
\hline No. & interval & Category & frequency & Percentage \\
\hline 1 & $9<\mathrm{X}$ & High & 22 & $73,33 \%$ \\
2 & $6<\mathrm{X} \leq 9$ & Is & 8 & $26,67 \%$ \\
3 & $\mathrm{X} \leq 6$ & Low & 0 & $0 \%$ \\
\hline Total & & & $\mathbf{3 0}$ & $\mathbf{1 0 0} \%$ \\
\hline
\end{tabular}

The mean of the context aspect was 9.83 and included in high category with $\frac{917}{960} x 100 \%=88,06 \% \mathrm{a}$ percent

\section{Student evaluation of input aspects}

Score Calculation

Highest ideal score (SMI) : 10x4=40

Lowest ideal score $: 10 \times 1=10$

Ideal mean $(\mathrm{Mi}): \frac{1}{2} x(40+10)=25$

Ideal standard deviation (SDi) $\quad: \frac{1}{6} x(40-10)=5$

From the results of the descriptive analysis, the effectiveness of the implementation of the Block System at Sekolah Harapan Harapan from the input aspect showed that the highest score was 36, the lowest score was 29, while the mean was 32.57 and the standard deviation (SD) was 2.10. The results of the analysis showed in Table 4

Table 4. Range of student scores from the input aspect

\begin{tabular}{|c|c|c|c|c|}
\hline No. & interval & Category & frequency & Percentage \\
\hline 1 & $30<X$ & High & 25 & $83.33 \%$ \\
\hline 2 & $20<X \leq 30$ & Is & 5 & $16.67 \%$ \\
\hline 3 & $X \leq 20$ & Low & 0 & $0 \%$ \\
\hline \multicolumn{3}{|c|}{ Total } & 30 & $100 \%$ \\
\hline
\end{tabular}

Thus, the mean of the aspect of input was 25.56 in the medium category with $\frac{977}{1200} x 100 \%=81,42 \%$ percent.

\section{Student evaluation of product aspects}

Score calculation

Highest ideal score (SMI) : 4x4=16

Lowest ideal score: $4 \times 1=4$

The ideal mean (Mi) $\quad: \frac{1}{2} x(16+4)=10$

The ideal standard deviation (SDi): $\quad: \frac{1}{6} x(16-4)=2.33$ 
From the results of descriptive analysis, the effectiveness of the implementation of the block system at Sekolah Permata Harapan from the aspect of the process known that the highest score was 15, the lowest score was 9, while the mean was 12.37 and the standard deviation (SD) was 1.63. The results of the analysis showed in Table 5.

Table 5. Range of student scores from the aspect of the process

\begin{tabular}{lllcc}
\hline No. & interval & Category & frequency & Percentage \\
\hline 1 & $12<\mathrm{X}$ & High & 17 & $16,67 \%$ \\
2 & $8<\mathrm{X} \leq 12$ & Is & 13 & $72,22 \%$ \\
3 & $\mathrm{X} \leq 8$ & Low & 0 & $0 \%$ \\
\hline Total & & & 30 & $100 \%$ \\
\hline
\end{tabular}

Thus, the mean of the process aspects was 10.83 in the medium category with a $\frac{\mathrm{a} 71}{480} \times 100 \%=77.29 \%$.percent

\section{Student evaluation of product aspects}

Score calculation

The highest ideal score (SMI): $5 \times 4=20$

Lowest ideal score: $5 \times 1=5$

Ideal mean (Mi)

The ideal standard deviation (SDi) $\quad: \frac{1}{a} x(20-5)=5$

From the results of descriptive analysis, the effectiveness of the implementation of the block system at Permata Harapan School from the aspect of the product known that the highest score was 16, the lowest score was 11 , while the average ( mean ) was 11.44 and the standard deviation (SDi) was 1,44 . The results of the analysis showed in Table 6.

Table 6. Range of student scores from product aspects

\begin{tabular}{ccccc}
\hline No. & interval & Category & frequency & Percentage \\
\hline 1 & $15<\mathrm{X}$ & High & 1 & $3.33 \%$ \\
2 & $10<\mathrm{X} \leq 15$ & Is & 29 & $96,67 \%$ \\
3 & $\mathrm{X} \leq 10$ & Low & 0 & $0 \%$ \\
& Total & & $\mathbf{3 0}$ & $\mathbf{1 0 0} \%$ \\
\hline
\end{tabular}

The mean aspect of the product obtained by the teacher was 11.44 in the medium category $\frac{299}{480} x 100 \%=83.12 \%$. percent

From the results of the data described above, it can be seen that each aspect and percentage obtained by both the teacher and student as follows:

Table 7. Recapitulation of each aspect along with categories and percentages obtained by teachers and students based on the evaluation of the CIPP model.

\begin{tabular}{|c|c|c|c|}
\hline No. & Aspect & Category & Percentage \\
\hline \multirow{5}{*}{1.} & Context & High & $88,06 \%$ \\
\hline & Input & High & $81,42 \%$ \\
\hline & Process & Is & $77,27 \%$ \\
\hline & Product & Low & $83,125 \%$ \\
\hline & & & $82,47 \%$ \\
\hline
\end{tabular}

\section{Qualitative Data Description}

Responding to research data collected through a questionnaire, researchers also collected data by conducting interviews with several informants, the Principal of SMK Harapan. Vice-principal of curriculum and department from three departments at SMK Permata Harapan. Qualitative data were analyzed in several steps, collection, reduction, data display, and verification. 


\section{Context aspects}

The purpose indicator of implementing a block system at SMK Permata Harapan was to provide convenience for students to be more focused on their learning because of the learning system uninterrupted from day today. Environmental indicators of the block system implementation at SMK Permata Harapan was a focusing environment that has many practical subjects so that it required continuous learning methods so that students can better remember and can continue the unfinished practicum on the previous day quickly. The problem indicator implementation of the block system at SMK Permata Harapan was the problem of scheduling and distributing teachers to avoid schedule collisions and the saturation that students have is quite high so teachers must be more creative to bring the classroom atmosphere.

\section{Input aspects}

Indicators of teacher education background in the implementation of the block system at SMK Permata Harapan, on average, college graduates and have a Strata 1 (S1) degree which proves that the teacher education background was good, indicators for teaching preparation in the block system implementation at SMK Permata Harapan This was quite good, because at the beginning of each block the deputy headmaster asked the teacher to collect teaching materials so that no unwanted obstacles occur in the classroom for the next block, the cost indicator on the implementation of the block system at SMK Permata Harapan that the costs incurred almost the same as the school applying the semester scheduling method, it's just that in the block system the benefits don't require many productive teachers for one class, because each teacher will teach every day in one class until the lesson is completed in one block, so productive teachers who teach in this block can return to teaching in next block without worried there is a conflicting schedule.

\section{Process aspect}

The implementation of the block system in Permata Harapan School having a complete learning system of one subject in one block (22 meetings) in one block there are five lesson sessions where one session consists of two hours of learning and one year there are eight blocks to complete all subjects that have been compiled in the curriculum, curriculum indicators on the implementation of the block system at SMK Permata Harapan are curriculum used in the implementation of the block system and are in accordance with the curriculum set by the government so that it can be concluded that the Permata Harapan School Curriculum is in accordance with the curriculum of the government and the same as other schools but the only difference is in the distribution of schedules, indicator solutions in the implementation of the block system at SMK Permata Harapan is the solution of the problem of saturation experienced by students is to provide student variations a difference in one block, so that students' brains can walk in balance between the left and right brains, for teacher schedule problems can be overcome by the addition of teachers if a schedule dispute that can not be avoided anymore.

\section{Product aspects}

The implementation of the block knowledge system of students increases rapidly because there is no gap between lessons from one another to make the ability to absorb student learning uninterrupted, the skill indicator on the block system implementation at SMK Permata Harapan is with the implementation of the block system of student skills so it quickly increases because there is no pause between practicum one with the next practicum which makes the ability to absorb student learning uninterrupted, the attitude indicator on the block system implementation at SMK Permata Harapan is the attitude of students with fellow peers is very good and has sense respect for older people, as evidenced by the habit of students greeting anyone who is met if deemed older.

From the context aspect of the average score (mean) was 10.57 of the maximum score was 12 , and 88.06\%. This score indicates that the context aspect obtained is included in the high category which means the score obtained from the opportunity and needs aspect of the block system in SMK Permata Harapan included in the good category. This includes the opportunities and objectives for the implementation of the block system due to the collaboration of all aspects involved, ranging from schools, teachers, and students. From the input, aspect score was 32.57 and a maximum score of 36 and $81.42 \%$, the input aspect is included in the high category which means the component of educators (teachers), students and the facilities and infrastructure provided by Permata Harapan School are good and the appropriateness of lessons with the curriculum set by the education service is at a good level. From the aspect of the process obtained an average score (mean) was 12.37 and a maximum score was 15 and $77.27 \%$, so the process aspects are included in the sufficient category which means the implementation of 
the block system is good and can find solutions to obstacles what happened during the process, in other words, the implementation of the block system was going well enough at Permata Harapan School.

From the aspect of the product obtained an average score (mean) was 13.30 from a maximum score of 16 , and $83.25 \%$, so that the product aspect included in the high category which means the results of the implementation of the block system have enough impact and affect students considered good. This can be seen from the continuous improvement of students' knowledge and skills.

The application of the block learning system provides opportunities for students to understand the material in-depth and focus without a lack of time. When the learning process carried out, students look relaxed and serious in understanding the material provided. Students can also easily understand the material presented by the teacher because of the 10 submissions that not too fast and explore the material. The LAB Board of Governor (1998) also conveys the advantages of the block system including (1) the block system allows students to concentrate on learning and dig deeper; (2) increasing students' grades and understanding because students can learn a lot in class and are better able to focus on their learning.

Block system learning can make students understand the material without being separated (one material can be completed with one meeting) so that when a test was done at the end of learning, students will more easily remember the material that has been delivered. In line with Nasution (2003) which states that the time factor is essential to mastering certain subject matter completely, and allows children to work through to completion (Suwati, 2008). The LAB of Board Governor (1998) also states "allows students to finish lessons quickly and can take the next lesson."

The results of this study following the advantages of the Block System. Has several advantages: (1) giving sufficient time for students to study the material in-depth (Marshak, 1998); (2) more children's learning time and allows children to work to the end (Suwati, 2008); (3) with longer blocks, teachers have more time to complete lesson plans and to examine and re-evaluate practices and Longer time blocks allow for in-depth studies, such as individual student projects, peer collaboration, and one-on-one work between teachers and students (O'Neil, 1995).

The implementation of the block system had a positive and effective effect in secondary schools. Kurniawan and Karsono (2012) stated that the Tri Wulan Block Learning System has effectively applied in SMKN 1 Jakarta, especially in Building Drawing Engineering Subjects. The overall results of this study can be concluded that the Tri Wulan Block Learning System implemented by SMKN 1 Jakarta, especially in the Productive Subjects of the Building Engineering Skills Program from the beginning of July 2011 until the end of June 2012 is effective. Likewise, with Swara (2019) the effectiveness of Islamic religious education learning with the normative block system in the Integrated Agricultural Vocational High School of Riau Province is categorized as "Very Good" because the final percentage obtained is $82.2 \%$ which is in the range of $81 \%$ to by $100 \%$.

\section{Conclusions}

Based on the analysis and discussion above, we can see that the context aspect included in the good category, the input aspect included in the good category, the process aspect included in the medium category and the product aspect also included in the good category, and the average TPR to the four aspects shows good results. also. This showed that each aspect has not been running optimally, therefore it is necessary to make improvements in each of these aspects to implement the block system to run better.

Based on the results of the study showed that the implementation of the block system at the Permata Harapan vocational high school was in a good category. For this reason, it is necessary to increase understanding and improve teacher performance in the future to be able to support the implementation of a block system following the context of the block system. The implication of this research is the need for schools to require each teacher to provide creativity in teaching students in the implementation of the block system to reduce the level of boredom and make students more enthusiastic in learning. Besides, the school must also provide facilities and infrastructure as well as increase teacher salaries so that everyone involved in the learning process feels comfortable and happy with their respective duties.

Based on the conclusions and implications of the study, it can be stated that the block system is feasible to continue at SMK Permata Harapan with several recommendations to help improve the implementation of the block system at Permata Harapan Vocational High School, improvement in various fields is very important such as providing access to facilities and infrastructure to students who need during class hours or outside class hours but have value benefits for schools or students, besides, schools 
must also provide direction to teachers to further motivate and encourage students so that the boredom received by students does not accumulate and have an impact on later learning outcomes

\section{References}

Abdul R. (2012). Deskripsi Sekolah Menengah Kejuruan. (Online). (http://eprints.uny.ac.id/8459/3,)

Alni, Nurul. 2019. "Pengaruh Persepsi Mahasiswa Tentang Implementasi Mata Kuliah Metode Blok Terhadap Motivasi Dan Capaian Prestasi Belajar." Jurnal Keperawatan Florence 4(1): 16-24.

Barnawi, Arifin \&. 2012. Etika Dan Profesi Kependidikan. Jogjakarta: Ar-Ruz Media.

Benny Heldrianto, 2013: dalam jurnal "penyebab rendahnya tingkat pendidikan anak putus sekolah dalam program wajib belajar 9 tahun desa sungai kakap kecamatan sungai kakap kabupaten kubu raya" http://jurmafis.untan.ac.id.

Depdiknas .2003. Undang-undang RI No.20 tahun 2003.tentang sistem pendidikan nasional.

Edi, Sarwo. 2017. “Pengembangan Standar Pelaksanaan Praktik Kerja Industri (Prakerin) Siswa Smk Program Keahlian Teknik Pemesinan di Wilayah Surakarta." Jurnal Ilmiah Pendidikan Teknik Kejuruan X.

Kurniawan, Emirda, Dadang Suyadi Ss, and R Karsono. 2012. "efektifitas sistem pembelajaran blok tri wulan pada mata pelajaran produktif program keahlian bangunan smkn 1 jakarta." Jurnal pensil jurusan teknik sipil FT UNJ 1(2): 123-31.

LAB Board of Governors. (1998). Block Scheduling: Innovations with Time. The Northeast and Islands Regional Educational Laboratory at Brown University. (Online). (http://www.brown.edu)

Lubis, Syahron. 2011. Metodologi Penelitian Pendidikan. Padang: Sukabima Press.

Majid, Asril. 2011. "Pengaruh Model Penjadwalan Dan Motivasi Berprestasi Terhadap Hasil Belajar Perawatan Sepeda Motor Siswa SMK." Jurnal Teknologi Dan Kejuruan 34 (1): 34-48.

Masbahah, Djoko Kustono, Syaad Patmanthara. 2014. "Efektivitas Sistem Pembelajaran Block Di Sekolah Menengah Kejuruan Kota Surabaya." Jurnal Teknik Mesin 1(1): 57-70.

Marshak, David. (1998). Key elements of effective teaching in block periods. Clearing House 72. Vol (1): 55-57

Mudyahardjo, Redja. 2008. Pengantar Pendidikan Sebuah Studi Awal Tentang Dasar-dasar Pendidikan pada Umumnya dan Pendidikan di Indonesia. Jakarta. Raja Grafindo Persada.

Muhibbin, syah. 2007. Psikologi pendidikan dengan pendekatan baru. bandung. Pt. remaja rosdakarya.

Nasution. (2003). Berbagai Pendekatan dalam Proses Belajar \& Mengajar. Jakarta: Bumi Aksara.

Notoatmodjo, Soekidjo. 2003. Pendidikan Dan Perilaku Kesehatan. Rineka Cipta. Jakarta.

O’Neil, J. (1995). Finding time to learn. Educational Leadership. 53(3): 11-15

Pemerintah Republik Indonesia, 2003. Undang Undang Republik Indonesia Nomor 20 tahun 2003 tentang Sistem Pendidikan Nasional (Sisdiknas). Jakarta

Prasetyo, Novian Yudha, Yoto. 2016. "Persepsi Mahasiswa Terhadap Efektifitas Pembelajaran Dengan Sistem Blok Matakuliah Praktikum Pada Jurusan Teknik Mesin Fakultas Teknik Mesin Fakultas Teknik Universitas Negeri Malang." Jurnal Teknik Mesin 2(2): 1-13.

Republik Indonesia. (2003). Undang-Undang Republik Indonesia Nomor 20 Tahun 2003 tentang sistem Pendidikan Nasional. Jakarta: Sekretaris Negara Republik Indonesia. 
Riduwan. 2006. Metode Dan Teknik Menyusun Tesis. Bandung: Alfabeta.

Swara, Anzas. 2019. "Efektivitas Pembelajaran Pendidikan Agama Islam Dengan Sistem Blok Normatif di Sekolah Menengah Kejuruan Negeri Tertanian Terpadu Provinsi RIAU.”

Suwati. (2008). Sekolah Bukan Untuk Mencari Pekerjaan. Bandung: Pustaka Grafia.

Wiyananti, Reni et al. 2016. "Prototipe Sistem Blok dalam Metode Pembelajaran Problem Based Learning ( Studi Kasus di Fakultas Kedokteran Universitas Muhammadiyah Semarang ).” Techno.com 15(1): 714.

Zepeda, Sally J. (1999). Arrange Time Into Blocks. Journal of Staff Development. 20(2) (spring): 26-30 